\title{
The Indonesianization of the Symbols of Modernity in Plaju (Palembang), 1930s-196os
}

\author{
Ida Liana Tanjung
}

\section{Introduction}

The process of decolonization, the transfer of power in a political or economic sense, is almost invariably accompanied by a change of symbols. When there is a transfer of power, it stands to reason that there will be a change in meaning of the symbols, which express the identity of the new party in control. Such symbolic changes help to communicate the political and economic changes to the society. The decolonization of Indonesia was accompanied by symbolic actions such as the Proclamation of the Independence of Indonesia in 1945, the displaying of the Indonesian flag all over Indonesia, and somewhat earlier, the ban on Dutch symbols during the Japanese occupation. The replacement of the symbols of the old regime by the new regime goes beyond the political and also embraces cultural symbols (Wertheim 1999:121).

As centres of political, economic and social activity, colonial cities produced colonial symbols on a large scale in Indonesia. Most colonial symbols were 'decolonized' following Independence in a process, which followed a similar pattern in almost all Indonesian cities. Most notable in this process was the destruction and replacement of the old colonial symbols, for example, statues commemorating a Dutch hero. These were typically destroyed and replaced by a monument commemorating heroes of the Independence struggle. This process of eradication was by no means complete, however, and not all colonial symbols were wiped out by the new regime (Colombijn 2006; Basundoro, this volume). Sometimes the new regime did nothing but attach a new, Indonesianized meaning to the old form. A good example is when a building of the former colonial state was allocated a new function by the Indonesian Republic, or when a street or urban quarter was simply given a new name. Therefore, if we want to understand the decolonization of colonial symbols, it is not sufficient to look at the creation of new symbolic objects; it is just as important to interpret the mutation in the meaning of existing symbols.

This interpretive approach to urban symbols is rooted in accepted theories of symbolism and signification. The locus of the symbolic meaning of an object always lies outside the object and is never inherent in the object itself. People can give new meanings to a 'symbol-carrier' (also called 'signifiant'), even when the

(C) IDA LIANA TANJUNG, 2015 | DOI 10.1163/9789004280724_013

This is an open access chapter distributed under the terms of the Creative Commons Attribution-

Noncommercial 3.0 Unported (CC-BY-NC 3.0) License. 
symbol-carrier itself does not change (Nas 1993:14; Ahimsa Putra 2002:2; Dillistone 2002:19; Nas, Jaffe and Samuels 2006:3, 7). In principle all objects can become a symbol. Social anthropologists have taught us that people's behaviour and physical elements created by people have symbolic meanings, as long as they can be associated with life events. Symbolic meaning is also just not restricted to material objects, it can also be found in gestures and behaviour, texts, and, what is important in this chapter, a certain area or neighbourhood. An area can become identified with a certain ethnic or social group. Often such particular visual elements of an area as architectural details or perhaps one particular building become a symbol for the whole area and its people (Dillistone 2002:22; Taal 2003:26).

In this chapter I will analyse the changing symbolic meanings of one urban area, namely Plaju, an oil company town in South Sumatra. Plaju presents an interesting subject for research because it was an economic enclave, geographically proximate to but socially distant from the city of Palembang. Palembang stretches along both sides of the River Musi, but the main parts of town lie on the west bank (called the Hilir or Ilir side). Plaju is located on the east bank (called Hulu or Ulu), about ten kilometers and slightly downstream from the centre of Palembang, but still within easy reach by boat (Manurung et al., 1956:256). ${ }^{1}$ It was only some time after Independence, in 1965 , that a bridge connected both banks, thereby opening overland transport between the city centre and Plaju. This raises the question of whether political changes, which were clearly felt in Palembang, the capital of the province of South Sumatra, reverberated in the company town, lying in relative isolation across the river. ${ }^{2}$ One particular question raised in this chapter is whether this company town lost some of its social exclusiveness as a result of decolonization.

Another interesting aspect of this question is that the decolonization of colonial symbols in Plaju was an unusually protracted process, as the Europeans who worked in the oil refinery continued to play a leading role after Independence. The Indonesianization of corporate enterprise (Lindblad 2008)

1 Some confusion exists about whether Plaju was in fact part of Palembang at the turn of the century (Nas 1995:137; McGee 1967:55; Taal 2003:66). In a sketch of Palembang in 1667, which was a major power at the time, Plaju was part of the city (Hanafiah 1998:77). A nineteenthcentury map of Palembang, however, places the urban boundary on the east bank of the River Musi at kampong 14 Ulu (De Clercq 1877:174), which excludes Plaju. Plaju was still not on the list of kampong names of the east bank (Seberang Ulu) of Palembang in 1934 (Hanafiah 1998:363).

2 A strong local symbol at the time was the name Sriwijaya. Sriwijaya referred to a once powerful ancient state, which had its centre near Palembang. After considerable debate, and pressure from President Sukarno, the local university and later a large fertilizer factory were named Sriwijaya (Vlekke 1959:27; Taal 2003:2; Fikiran Rakyat 3-6-196o, 13-6-196o, 20-8-1960). 
proceeded at a slower pace than did the decolonization of political symbols. This raises the question of how the slow pace of economic decolonization interfered with the symbolic decolonization in Indonesia. European managers of the oil refinery, the central Republican government, and the local government of Palembang all had an interest in this oil company town. The upshot was that they were constantly in conflict with each other. They were in competition to take control of such urban symbols in Plaju as houses, buildings, and street names.

In short, Plaju is a special case, because it was relatively insulated from national, political changes in two ways: its geographical isolation from Palembang and the continued presence of Western managers. The company town was also special in a third way: it was not only, and perhaps not in the first place, a symbol of European might, but a symbol of modernity. Its attraction for Indonesians may have relied less on the wish to uproot the Dutch from Indonesian soil, than the desire to acquire its modernity.

The theme of this chapter is a discussion of the decolonization of colonial symbols in Plaju, where this process apparently ran a different course than in other cities in Indonesia. The work is based on a survey of literature and newspapers about Palembang and Plaju, and interviews which took place during a two-month period with retired refinery staff in Plaju and Palembang. ${ }^{3}$ Before moving on to understanding the symbolic changes, it is essential to sketch the simultaneous social changes that took place at the time.

\section{Origin and Development of the Oil Company Town Plaju until the Second World War}

In 1897 Jan Willem IJzerman, head of the Muara Enim Petroleum Maatschappij, planned to establish an oil refinery in Plaju. At the time Plaju was nothing more than a small kampong. The Musi Ilir Petroleum Maatschappij also built a

3 Djohan Hanafiah, Palembang; Ramli Sazili, Subdistrict head of Plaju; Syamsudin, Plaju Ulu groove; Husni Majeri, Hubmas Pertamina Plaju (Public Relations of Pertamina Plaju); Hasanuddin Saji, Bagus Kuning; Erwinsyah, Fasum Pertamina Plaju (Public Facilities of Pertamina Plaju); Makmum Murod, Kompleks Pertamina Plaju groove; M.Sihut, Ladang Plaju groove in 1970; Hasan, Kepala Bagian Hukum dan Pertanahan Pertamina Plaju (Head of Law and Land Affairs); Nawawi (retired of в PM), Plaju; Edy Thamrin, Plaju; Bawaihi (retired of в Рм), Tangga Takat; Bakrie Syafar (retired of врм), Plaju. The names at the interview list are only a part of 50 respondents who were interviewed in January and April 2005. 
smaller refinery in Bagus Kuning, a village near Plaju. Both these refineries, which covered an area of about 100 and 21 hectares respectively, became property of the Anglo-Dutch Royal Dutch Shell in the first decade of the twentieth century. They were operated by the Bataafsche Petroleum Maatschappij (в Рм, Batavian Oil Company), a subsidiary of Royal Dutch Shell (Bartlett et al., 1986:46; De Bruyn Kops 1919:124; Lindblad 2002:105). To improve production, BPM closed the Bagus Kuning refinery in 1909 and focused on oil refining in Plaju. The Plaju refinery had the advantage of producing marketable secondary products and its location near a good river infrastructure ensured refined products could be efficiently transported to Java and Singapore by big ships (Pertamina 1995:3; Purwanto 1997:90). In 1912, Standard Oil (later Standard Vacuum or Stanvac) started a refinery at Sungai Gerong, directly downstream from Plaju.

When it established the Plaju refinery, ВРм also built houses for its labourers. These were located near the refinery but separated from the indigenous kampong Plaju, from which the refinery had derived its name. These houses would form the beginning of the company town Plaju. At first the houses were built in Malay style on piles, not markedly different from the kampong houses. A house on piles (kolong house) was ideal in the local environment, because the river at Plaju was still tidal. Moreover, during the rainy season, the River Musi used to flood the lower areas, which temporarily would transform the area into a swamp (lebak) (Peeters 1997:37; Stibbe 1919:332). The existence of swamps and wetlands meant that houses could not be built directly on the land. The draining of swamps would have been an expensive undertaking, as soil and pebbles had to be imported from outside Palembang. It was only after the oil industry in South Sumatra made spectacular progress in the second decade of the twentieth century and Plaju grew into the biggest refinery in Sumatra (Zed 2003:71) that BPM started to build on the ground in Plaju and abandoned the method of construction on piles. The new Plaju complex was equipped with various convenient facilities, including a water supply, a tennis court, swimming pool, club, hospital, and shopping mall (Nas 1995:140).

Colonial cities were home to a diversity of people of different ethnic, social, cultural, and religious backgrounds (Yeoh 1996:1). Typically social stratification was based on the tripartite 'racial' categorization of the Netherlands Indies in which Europeans were the upper class, Chinese the middle class, and the indigenous people the lower class. Plaju also formed a multi-ethnic society, but one in which the composition was somewhat unusual. The oil industry, which was supported by large capital investments and advanced technology from foreign oil companies in the Netherlands, the United Kingdom, and the United States, attracted many Westerners to this small place. Expert staff was recruited 
from the Netherlands, Britain, the United States, Canada, Russia, Rumania, Japan, Germany, Poland, and other European countries (Purwanto 1997:92). These Europeans, Americans, and Japanese were all classified as 'European' in the colonial legal tripartite division. Compared to companies in Palembang, the refinery of Plaju stood out because of the number of European technicians it employed. In 1926208 European employees worked there and in 1929 this number had increased to 475 (Zed 2003:79).

While Europeans worked as experts, Indonesian and Chinese labourers, generally referred to as Asian Labour, did the rough work. However, there was no recruitment of contract labourers in Java and China as had been done earlier for the plantation in East Sumatra, and the tin mines of Bangka, and Belitung. Some of the Asian Labour came from South Sumatra; the rest came from outside South Sumatra. These people had actively looked for a job in the oil companies and after they had been taken on were categorized on the basis of their qualification, as skilled manpower or semi-skilled manpower. Between 1924 and 1926, 80 per cent of the workers in the oil industry came from South Sumatra, and 20 per cent from outside, primarily from Java and China (Zed 2003:77-79). Unlike the indigenous population in Java and perhaps Palembang, which was vertically divided into status groups (Wertheim 1959:138-141), the Indonesians in Plaju were not further subdivided.

This socio-ethnic categorization of the oil company was reflected in the spatial layout of Plaju. The European settlement was deliberately located at quite some distance from the refinery so that its inhabitants would not be disturbed by industrial noise and pollution. The Indonesian settlement was located in the vicinity of the refinery. It is not entirely unclear where the Chinese settlement would have been. However, according to retired staff members of the refinery, there was a Chinese school in front of the Plaju hospital, on the main street and I presume that the Chinese settlement was not far from that school. ${ }^{4}$

The type of housing in Plaju revealed the cultural origin of the inhabitants. Most of the European houses were of what can be described as Indies architecture, which was a hybrid style of modern architecture from the Netherlands adapted to the tropical climate in Indonesia (Handinoto 1996:163; Figure 12.1). The houses were neat and had a spacious yard embellished with flowers and green lawns; the ВРм employed gardeners to maintain the greenery. One contemporary observer, Broersma (1921:35-37), admired this 'petroleumstad'

4 Interview, April 2005. At least until the 1930s, there was one Chinese primary school, which had 350 students (Rivai 2001: 70). The Dutch destroyed it together with the refinery during the Second World War; later the location was used as a tennis court according to a map of the Plaju complex in 1956. 


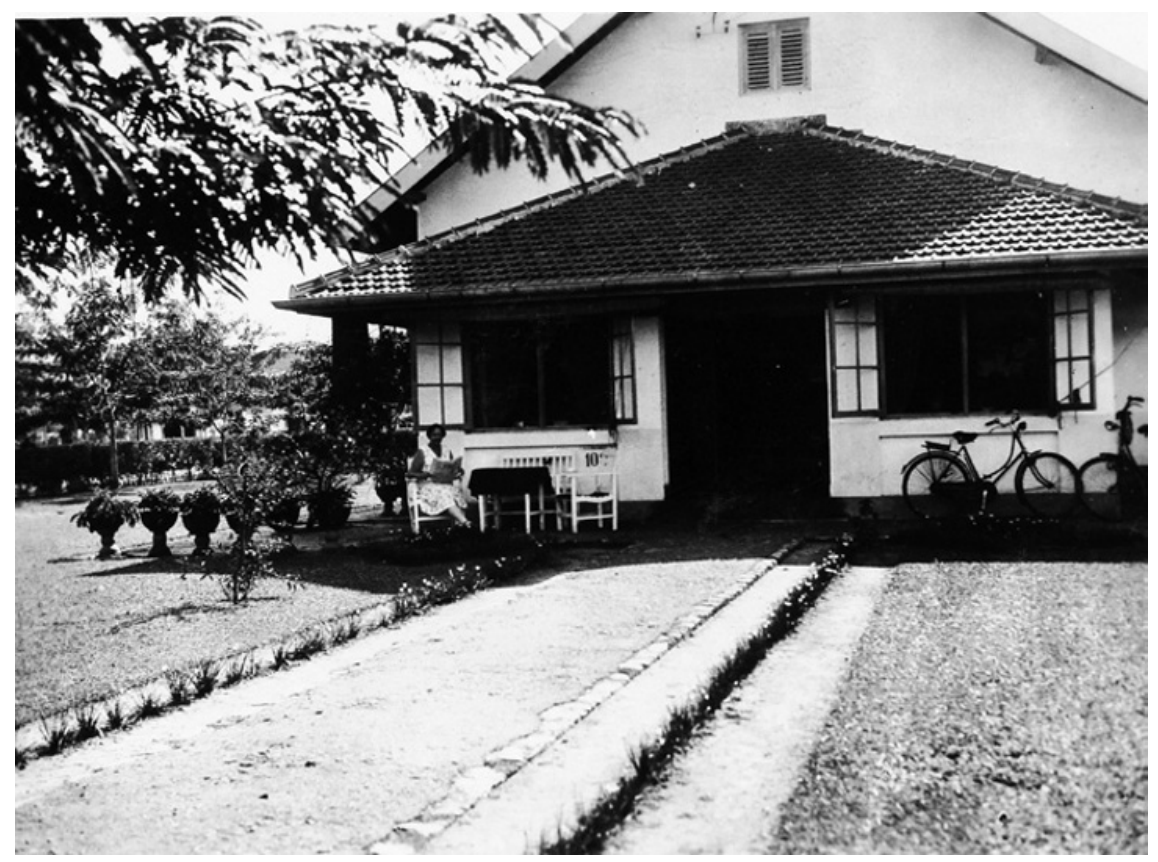

FIGURE 12.1 The house of European staff of the BPM Plaju in 1930

SOURCE: KITLV COLLECTION 158486. COURTESY OF KITLV/ROYAL NETHERLANDS INSTITUTE OF SOUTHEAST ASIAN AND CARIBBEAN STUDIES, LEIDEN

(oil town). According to him, Plaju was really different from Palembang, which, in contrast, he deemed dirty and disorderly. ${ }^{5}$

However Broersma's favourable opinion could not count for the whole of Plaju as the condition of the Indonesian settlements was less salubrious. Indonesian labourers lived in barracks that were equipped with a common kitchen and bathroom. Each barrack block was inhabited by more than one family and was colloquially named by their residents after a tree or bird in the area, such as Tangsi Burung (Bird Barrack) and Tangsi Duren (Durian Barrack). The reason the residents used the name Tangsi Burung was, allegedly, because the building looked like a birdcage and the name Tangsi Duren was used because of the many durian trees around the house.

Besides housing, В Р also provided various facilities in Plaju for the refinery staff, but again, differences existed between the various categories of employees. A club (sociëteit), swimming pool and tennis court were facilities

5 Kerchman (1930) and Sandra Taal (2003) also described Palembang as a dirty city with slums. 
that conveyed an image of modernity, but these facilities were located in the European area. The function of these facilities and their location emphasized colonial social distinctions between indigenous and European people. The company also built shops to fulfil the basic requirements of the refinery employees, but the European shop was quite different from the Asian shops, as the Europeans required different goods. The European shop was known as Civo Laut (Sea Civo), because of its location at the Musi River and because most goods - like alcoholic drinks, clothes, and canned food - had come from overseas. Asian employees did not dream of shopping at Civo Laut and BPM had provided them with a shop of their own which was called Civo Darat (Land Civo). Here one could buy various Asian necessities like rice and clothes. Vegetables and fish were commonly bought from merchants from outside Plaju who were generally passing through by boat. ${ }^{6}$

\section{Early Indonesianization of Plaju's Modernity, 1930s}

In the 1930s, the oil industry was growing rapidly in South Sumatra; there were about 35 oil-mining concessions in the area. The oil industry activity was not just restricted to the actual oil fields. Huge pipes hundreds of kilometres in length, connecting hundreds of drill towers, oil pumps, and storage tanks, covered the area before finally reaching the refinery in Plaju (Zed 2003:79-80). The company did not want to only rely on water transportation between the refinery and the oil fields, and this concern led врм to build a road network in South Sumatra as well. The development of the oil industry had thus an enormous influence on the whole region. Local communities could use the roads and attend schools that were also established by вРм. вРм established 42 schools throughout South Sumatra before the war (Rivai 2001:70).

Therefore, from the people's point of view, the oil industry in Plaju was a symbol of modernity and prosperity. Working at one of the oil companies around Palembang became a dream for many educated youth in the 1930s, although they had to compete with people coming from outside South Sumatra (Zed 2003:80). The increased participation of educated Indonesians in the oil industry in the 1930s caused a shift within the Indonesian labour force, as now also indigenous people became part of the staff of B РM, as supervisors, technicians or administrators (Purwanto 1997:92). Previously these positions had only been occupied by European staff.

6 Interview, April 2004. 
The Indonesianization of the staff of the refinery had, as corollary, the early decolonization of colonial symbols in Plaju, long before political independence was achieved. For example, before the 1930s the societteit (club) was a colonial symbol of European modernity and a space that could only be used by European staff (Figure 12.2). After the entry of Indonesians in the higher echelons of the refinery, another club was opened for the Indonesian staff, Sociëteit Kranie. For the Indonesian staff, the societteit was not only a social club, but also formed a way of becoming acculturated to the new culture and it was a symbol of their newly won status. The Indonesian staff at the refinery conveyed their status and new identity in their behaviour, as they started playing table tennis, dancing, and gambling. ${ }^{7}$ Because of the dancing, both the European sociëteit and the Indonesian sociëteit were better known as kamar bola (ball room).

In their desire to take part in modern life, the Indonesian staff also tended to use Dutch, although typically mixed with Indonesian. A local newspaper reported the following: 'When they spoke, Malay was mixed with some Dutch,

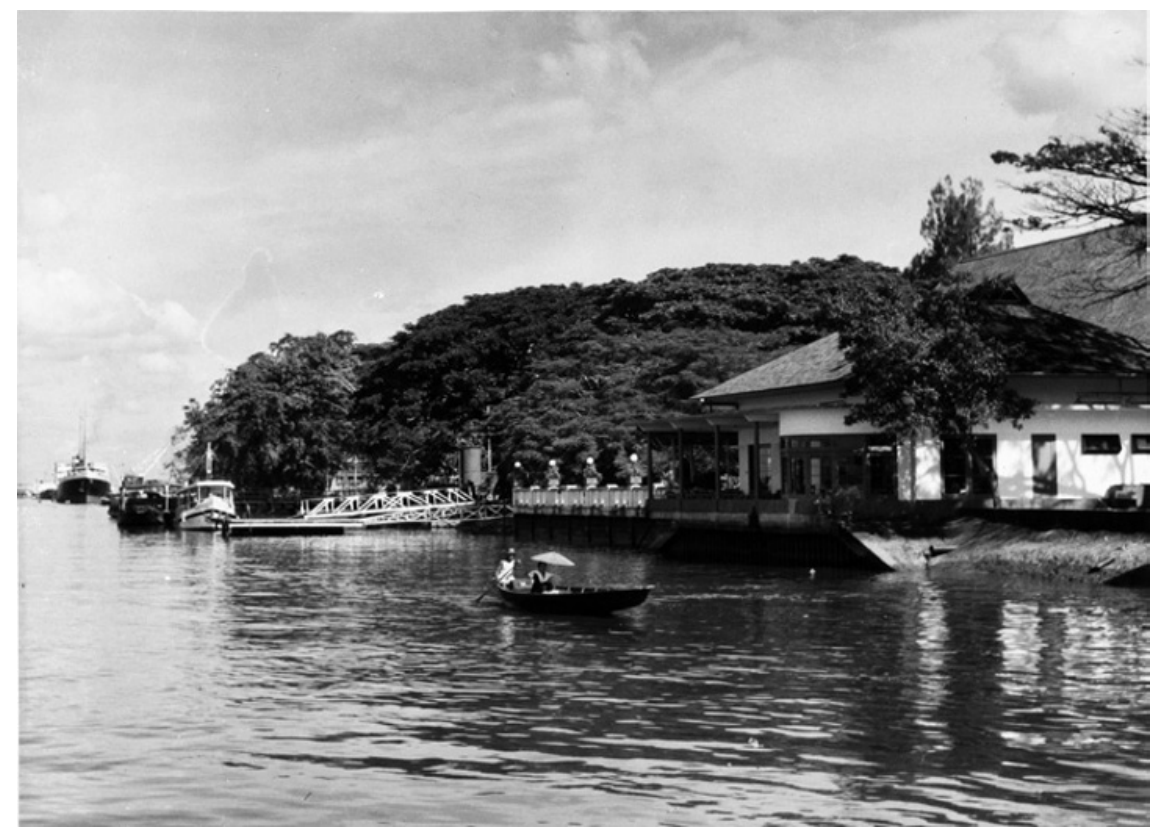

FIGURE 12.2 The sociëteit of BPM/Shell at Plaju, on the River Musi in 1955 SOURCE: KITLV COLLECTION 52668. COURTESY OF KITLV/ROYAL NETHERLANDS INSTITUTE OF SOUTHEAST ASIAN AND CARIBBEAN STUDIES, LEIDEN

7 Interview, April 2005. 
although clumsily, because they had not really mastered that foreign language.' 8

In religious matters, however, Indonesians of course chose their own path and did not follow the European attendance of Christian services. A mosque was erected in the Indonesian part of Plaju, funded by the profits of the night market (Han Po 11-6-1931). A church, incidentally, was not erected in the European area of Plaju until the 1950s. For years, religious services were held in a school and eventually in the photo and film club Het Brandpunt (Dunia Minyak December 1956).

Remarkably, not only did Indonesians adopt Western manners, the European staff also copied elements of Indonesian behaviour. In the 1930s, BPM implemented a policy of conscious hybridization. It recommended that traditional clothes (sarong and kebaya) and the Malay language should be used by Europeans in the household in order to become more aware of the Indonesian culture in their daily lives (Pattynama 2004). Plaju was a special case in this respect. In 1930 the ВРм announced to its European staff that they should learn Indonesian as fast as possible in order to become more connected to their Indonesian co-workers. The В Рм would raise the salary of everybody that could speak the language (Pertja Selatan 23-1-1930).

The blending of lifestyles in Plaju also became apparent in housing. The BPM had built brick barracks for their labourers using a vernacular style of roof while Indonesian staff occupied houses not far from those barracks (Figure 12.3). Meanwhile, B PM used local architectural elements (again a peculiar, vernacular shape of the roof) for houses that were intended for the European staff creating houses that looked quite similar to those built by the N.V. Volkshuisvesting in Kali Salak, Surabaya, in 1927 intended for middle class Indonesian households (Handinoto 1996:115).

Even Indonesians who were not employed by the вРм took part in the modernity of the refinery, although this gave rise to some misgivings on the part of the European management. Not all Indonesian labourers could be housed inside the complex and they were forced to look for accommodation outside, for example in the nearby Kampong Bali and Kampong Plaju. As a consequence, the increased interaction between the refinery labourers and the kampong residents made the company town more accessible to the kampong people. Concerned that this might affect the safety of the refinery, BPM

8 'Marika kalau ngomong-ngomong sedikit-sedikit hindia dicampoeri dengan bahasa Belanda meskipoen kakoe, sebab memang tidak pandai bahasa asing itoe' (Pertja Selatan 23-1-1930). 


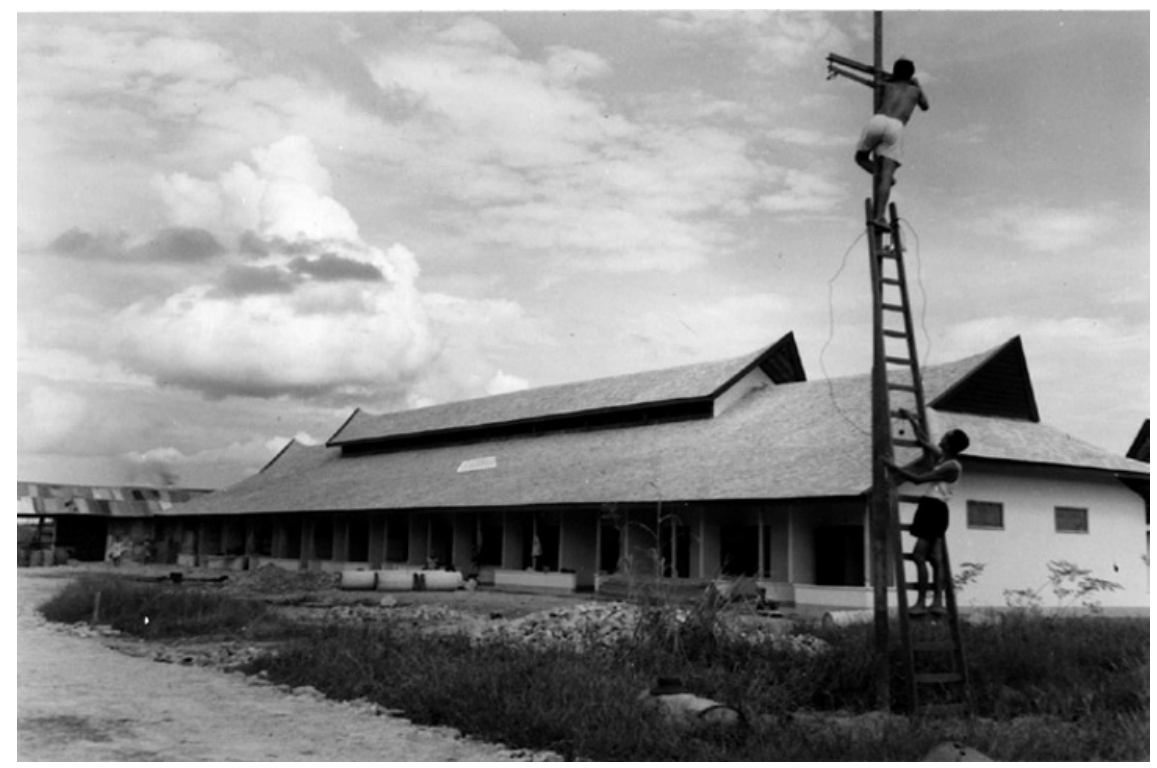

FIGURE 12.3 Barracks with vernacular-style roof for BPM labourers, 1930 SOURCE: KITLV COLLECTION 16746. COURTESY OF KITLV/ROYAL NETHERLANDS INSTITUTE OF SOUTHEAST ASIAN AND CARIBBEAN STUDIES, LEIDEN

management decided to establish a front gate and a guard post in 1934 . Henceforth, Indonesians had to have a token from в Рм as a kind of identity card to enter the refinery compound. This was reported by Pewarta Palembang as follows: 'All workers, both coolies and clerks, in short all Asian personnel, were given a token by в Рм; and not just that, they were also photographed; hence the regulations were tightened. 9

Although the ВРм kept the kampong inhabitants out of the refinery, it could not prevent them from benefiting from the modern goods available in its stores. Refinery workers received an allotment from the вРм in the form of clothes, rice and kerosene. Typically, some of these goods were sold to kampong residents with the result that their appearance became increasingly similar to that of a refinery worker. Nevertheless, some differences remained. A son of a refinery worker remembered that when he went to school, he wore shoes

9 'Segala penggawe-penggawe baik dari koeli maoepoen krani-krani, pendeknya seantero dari aziatisch personeel masing-masing mereka oleh BPM diberikan tanda penning dan tidak itoe sadja, tapi masing-masing mereka djoega diportret, maka djoega dikeraskan peratoeran' (Pewarta Palembang 3-11-1934). 
and his kampong friends did not, because their fathers were not refinery workers. ${ }^{10}$

The modernity of the oil company town of Plaju was not only apparent in terms of its outward appearance, but also evidenced by awareness of its inhabitants of how to live hygienic, healthy, and neat lives. So, when the local newspaper reported that Plaju had been infected by cholera and typhoid (Pertja Selatan October 1930), the в Рм was not amused, since that news damaged the modern image of Plaju. B Pм complained to Pertja Selatan that because both cholera and typhoid were associated with slum areas, these diseases could not possibly have infected Plaju. In the next issue Pertja Selatan amended - or rather self-censored - its previous chapter, reporting instead: 'In B Рм (Plaju) there has never been outbreaks of cholera, typhoid or influenza, because of the surveillance of public health, which is provided for its inhabitants'.11

Various efforts were undertaken by the ВРм to maintain this clean and healthy image of Plaju. For instance, the в Рм also established a big hospital on the compound, the first hospital in Seberang Ulu, the south side of the River Musi. ${ }^{12}$ Refinery workers who had intentionally scribbled on a public bathroom wall were sacked (Pertja Selatan 13-3-1930). From the point of view of the directors, the graffiti defiled the clean image of the company. From the perspective of the labourers, however, their deed can be seen as an act of resistance: a way of appropriating public space. It was a symbol of the Indonesianization of Plaju, albeit a symbol of the weak, who had no other outlet to express themselves and who were denied access to the consumption of modernity.

\section{Plaju During the Japanese Occupation and the Struggle for Independence}

In the Second World War Palembang was the main Indonesian target of Japan, because half of the oil production in the Netherlands Indies flowed through that city. On 14 February 1942, 6oo paratroopers landed at one of the airfields of Palembang and around the two refinery complexes at Plaju in a surprise attack. The Dutch authorities had planned to damage the refineries to put them out of

\footnotetext{
$10 \quad$ Interview, April 2004.

11 'Di вPм (Plaju) tidak pernah ada penyakit cholera, typus dan influenza, karena boeat djaga kesehatan pendoedoek telah dikabarkan/disediakan tempat oentoek keperloean' (Pertja Selatan 1-11-1930).

12 Nationaal Archief, The Hague (NA), Memorie van Overgave W. Steinbuch, Resident Palembang 1933-1936:286.
} 
commission for six months, in the expectation that by then the Japanese would have retreated. In effect they miscalculated, not only about the time the Japanese would stay, but also the speed of the Japanese advance on Plaju. In the chaos of their retreat, the refineries of В Рм and Standard Oil were only slightly damaged. The Japanese soon restored the oil installation, which was in full swing within half a year (De Jong 2002:35-36).

After their conquest, the Japanese quickly suppressed all symbols of Dutch rule such as the flag, portraits of Queen Wilhelmina and other members of the Royal Family, images with the words 'Nederland zal herrijzen' (the Netherlands will rise again), V-badges and buttons with a $\mathrm{W}$ on them worn by officials. Furthermore the use of Dutch or English language in public was prohibited and Japanese or Indonesian had to be used instead (De Jong 2002:69). BPM was renamed Dai Ici Seiyuzo (Alumni Pendidikan Tehnik Minyak Plaju 1999:6) and the names of buildings and streets in Plaju were replaced by Indonesian ones. Naturally, the Japanese did not destroy the colonial buildings, housing and facilities, but reused them for military purposes. As the oil refineries at Plaju and Sungai Gerong were a strategic place, they became two of the four headquarters of Japan in Palembang (Taal 2003:71) (Table 12.1)..13

The only legacy of this Japanese period that has remained in Plaju until today is the oil engineering school, a symbol of Japan's lack of expertise needed to run an oil industry at that time. When Japan took over the oil refinery they were short of competent experts. Most of the staff, who worked for the Japanese

TABLE 12.1 Number of students at the oil engineering school in Plaju, 1942-1945

\begin{tabular}{llc}
\hline Year & Level & Number of students \\
\hline $1942-1943$ & Minaraiko & 100 \\
& Sekiyu Ko Yoseijo & 200 \\
$1943^{-1944}$ & Minaraiko & 100 \\
& Sekiyu Kogiyo Gakko & 400 \\
$1944-1945$ & Sekiyu Kogiyo Gakko & 400 \\
\hline
\end{tabular}

SOURCE: ALUMNI PENDIDIKAN TEHNIK MINYAK PLAJU (1999:15)

13 The other two Japanese headquarters in Palembang were Talang Semut (a former European settlement), and the airport to the north of the city. 
in the oil projects in Indonesia had been taken directly from school and lacked practical experience. Therefore the Japanese recalled staff who had formerly been employed at the oil installations, in order to get them back in operation as quickly as possible. In April 1942 the Japanese brought about 300 oil workers from Java to Palembang to work at the refineries (De Jong 2002:50). However, most of the staff that worked for the Japanese had only been ordinary labourers during the Dutch era, and as a result Japan later decided to establish an engineering school in Plaju to upgrade the skills of these labourers, as well as to train all young people from the Palembang region who had previously attended a Hollandsch Inlandsche School (HIS, Dutch Language Elementary School) or Meer Uitgebreid Lager Onderwijs (MULO, Advanced Elementary Education). Many of them came from the environs of Palembang (Bartlett et al., 1986:56; Alumni Pendidikan Tehnik Minyak Plaju 1999:15). In total, almost 1,200 people followed the oil engineering education during the Japanese years. Although the quality of the lessons was not as hoped for, the oil engineering school was the first attempt to train Indonesian people in the oil industry (Bartlett et al. 1986:57).

After the Japanese surrender and the proclamation of the Indonesian Republic, Plaju was taken over by the young Republic. The management was transferred to one department of the Palembang Residency, the Mine and Oil Division, headed by Dr M. Isa. Isa was the former chairman of Partai Indonesia Raya and the founder of the militant oil labour organization Persatoean Pegawai Minyak (PPM, Union of Oil Workers) that sided with the Republic and which, after Isa became head of the Mine and Oil Division, was headed by Salam Faiman. To celebrate the transfer to the Republic the oil labourers of the Plaju refinery organized a big party in restaurant 'Asia' (Zed 2003:338-339).

The new Republican leaders were initially euphoric about controlling the biggest refinery in Palembang but they soon had to face the return of the ВРм, coming on the heels of the Allied forces that sought to regain control of the oil industry. Consequently the Plaju refinery became a contested area. On the one side there was the government of the Indonesian Republic in Palembang and the oil workers association РPM, and on the other side, the в Рм (Shell) that was the owner of the refinery before the Second World War (Basundoro 2004:7). The conflict was solved by the so-called 'olie diplomasi' (oil diplomacy). The district head of Palembang, Dr Ak Gani, proposed a division of tasks to the allied forces, which resulted in an agreement about oil production quota. On behalf of the Republic, PРм would hold the concession, while в вм (Shell) became the actual operator of the refinery (Zed 2003:359-36o). This successful diplomatic effort by Ak Gani in fact represented the first step towards the 
nationalization of the most important economic resource of South Sumatra. However, because of financial constraints, complete nationalization could not be carried out entirely at that moment. The Republic needed the foreign company as investors. During the first year of the Revolution, the installations at Plaju were guarded by a Japanese battalion, Asano Butai. In August 1946 the Japanese finally transferred the guarding of Plaju to the Allied forces (Mangkualam 1986:72; Zed 2003:360). In the next month, on 23 September 1946, the management of the Plaju refinery was transferred back to its initial owner, namely the вРм (Manurung et al., 1956:126).

After the transfer of sovereignty to the Indonesian Republic by the Dutch in 1949, the в Рм lost something of its political protection and the company had to become more responsive to public demands. This became clear, for example, in a land dispute in 1956. In 1956, a plot of land located in Kampong Ladang Plaju, but owned by the в Рм, was sized by the government and given to the kampong residents. ${ }^{14}$ On other occasions kampong residents took the initiative to request the government to take over В Рм assets, and those requests were not limited to land. In one case the local government was urged by residents to take over the wall that surrounded the в Рм complex, because according to the residents, this wall was very disturbing to the people living next to it (presumably because their free passage was blocked). Consequently, the municipal council ordered в Рм to demolish its wall and to give the debris to the kampong residents so that they could pave a path. Although this time the local administration did not back the kampong residents, and the request was refused by the ВРм, the request was unmistakably an effort of the local population to break into the exclusiveness of the Plaju complex.

\section{The Entry of the Army in Plaju}

One unforeseen consequence of the struggle for independence was a struggle for housing and land between the state, corporate enterprise, and the various groups of armed forces. The в Рм and Stanvac oil companies each gave up between 50 and 60 houses to the Dutch army during the Revolution to protect Palembang against Republican forces (Colombijn 2010:259-26o, 341-343). The main object of the army was to take possession of the so-called 'Rumah Pintu Besi' (Iron Door Houses), whose doors were made of iron (Figure 12.4). The Iron Door Houses were located at 6oth, 61th, 63th, 64th, and 65th Street, 


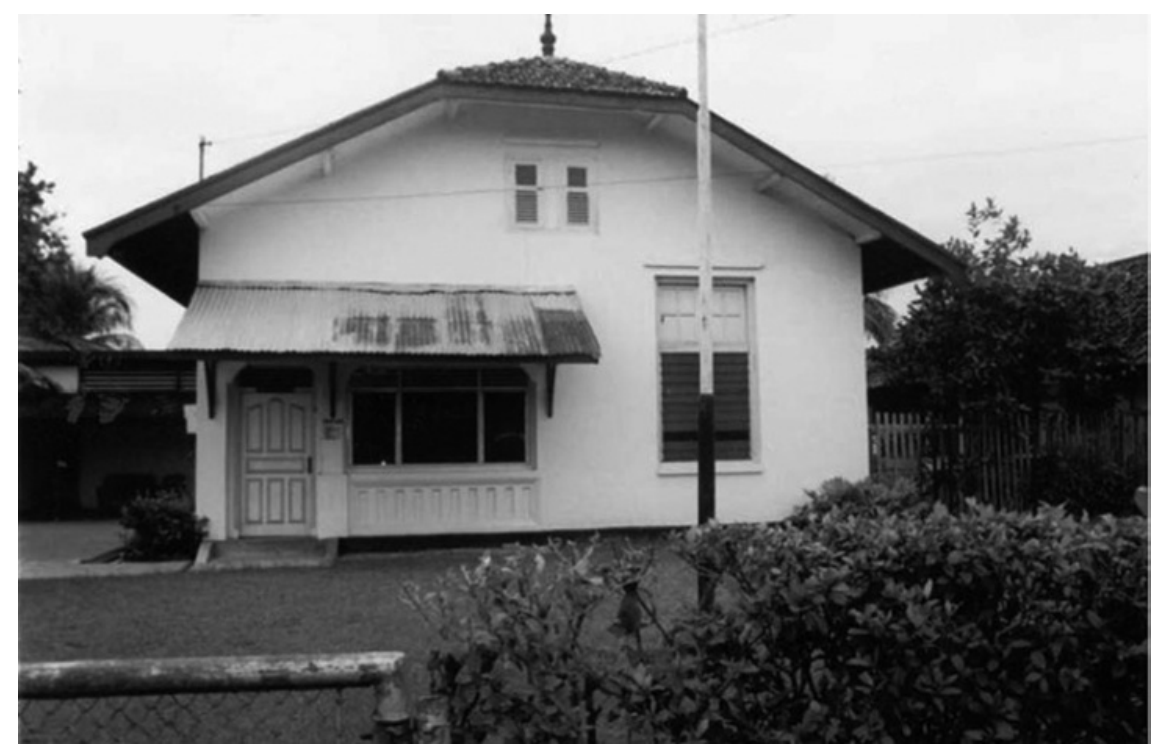

FIGURE 12.4 An Iron Door House in Plaju

PHOTOGRAPH: IDA LIANA TANJUNG

just outside the refinery, but were still considered part of the oil complex. They were among the first houses that were built by the в Рм for European employees, especially house number 1 to 7 .

The transfer process of the Iron Door Houses to the military began when Plaju came under control of the Allied Forces in late 1945. The Allied Forces initially claimed some of the houses of в Рм that were strategically located in front of the Plaju complex. After the Allied Forces left Palembang on 9 November 1946 (Zed 2003:413), the Koninklijk Nederlandsch-Indisch Leger (KNIL, Royal Netherlands Indies Army) took over the Iron Door Houses. ${ }^{15}$ Later, the Indonesian army took over the European houses that were occupied by the Dutch Army, including the Iron Door Houses, but not other houses in Plaju. The other European-style houses in Plaju continued to be occupied by European and Indonesian employees who held the higher functions in the refinery's administration and operation. ${ }^{16}$ In other words, the European style

15 The upshot of the Dutch return was mounting violence perpetrated by both Republican and Dutch forces in Palembang from November until December 1946. The violence reached its climax in what Palembang residents call Pertempuran Lima Hari Lima Malam (the Battle of Five Days and Five Nights), taking place around 1 January 1947 (Mangkualam 1986:111-166; Zed 2003:415).

16 Interview April, 2005. 
houses in Plaju expressed both change and continuity in the political domain (Evers 1993:83). The transfer of the Iron Door Houses to indigenous occupants symbolized the liberation of Indonesia and the Indonesianization of urban space. On the other hand, the return of Europeans to Plaju in 1945 and continued occupancy of houses by oil company staff reflected a continuation of the image of Plaju as an exclusive settlement, which continued to exist at least until 1965 .

The significance of the presence of the army also became increasingly apparent. In a land dispute case in $195^{2}$ W.G.J. Vesseur, representative of the вPм in Sumatra, lodged a complaint to D.I Pandjaitan, Commander of the Territory II/Sriwijaya South Sumatra Division. The complaint concerned the army's use of land of the former NV Nomura Oost. This former plantation belonged to the Japanese rubber export firm Nomura Shokusan Company, which was taken over by Lee Rubber, the biggest rubber export company in Palembang, which had its main office in Singapore (Zed 2003:387). The в мм had purchased the land belonging to NV Nomura, which was located next to the Bagus Kuning complex, in $1951{ }^{17}$ Its is probable that the BPM controlled only a part of this land, the other part of the Nomura land being in the hands of the Indonesian Army. The Army had built a barrack, which crossed the boundary with the Bagus Kuning complex. Vasseur proposed to the Army either of two options: either to pay rent for the use of the land and buildings, or to demolish the barrack, so that в Рм could erect a border wall. ${ }^{18}$ The commander of the Sriwijaya Division rejected both options and suggested instead that if ВРМ wished to build a wall around its compound, it should be built at at least five metres distance from the barrack. ${ }^{19}$ The land dispute continued for years, until the nationalization of ВРм in 1958-1959, when the ВРм was finally forced to transfer a large part of its assets, including the land of NV Nomura, to the Army. ${ }^{20}$

\section{Changing Names of Streets and Buildings in Plaju}

The gradual Indonesianization of the higher echelons of the staff of the refinery, which started in the 1930 s and continued at a faster pace in the

\footnotetext{
17 Archive of HKP UP III Pertamina, Plaju (HKP), Recht van Eigendom of the Nomura land No. 108/p, 8-12-1951.

18 HKP, letter No. 5270, 22-9-1952.

19 HкP, letter Commander T.T II/Sriwijaya to Deputy of Sumatera BPм. No. K 84/SN/T.T.II, 3-2-1953.

20 HKP, letter General Manager Sumatera BPM, C. Hull, 14-12-1959.
} 
1950s, was reflected in the changing symbolic landscape in Plaju. Names of streets and places have significant symbolic meanings, which provide information about the ideas and interests of the names they record (Yeoh 1996:221). When New Guinea was excluded from the territory of the Indonesian Republic in 1949, many Indonesians felt very disappointed, and as a result the dislike of the Dutch reached a point that all associations with the Dutch colonial past had to be wiped out. One form of this process of erasing the remnants of Dutch colonialism was the changing of street names and names of buildings. This, as Sandra Taal (2003:154) has argued, was of particular significance because unlike for instance statues, streets are found everywhere.

According to Peter Nas (1993:30) street names can convey so-called collective, historical and projective memories. Projective memory applies particularly to streets laid out as a grid, in which streets are merely numbered and do not get a more individual name. In Plaju, street naming was based on such a system, which was appropriate for a new town, enabling it to be expanded systematically in the future. In colonial times, the BPM had named all streets in Plaju Weg (Road) followed by a number (Weg 1 until Weg 71).

After Independence, the municipal governments changed most Dutch names in their respective cities. Many local administrations chose to name the main streets after national heroes from the Revolution or earlier times and as a result almost every Indonesian city has a uniform pattern of names that emphasize national identity (Taal 2003:155). However, this was not the case in Plaju, because the company town was out of reach of the nationalist municipal government of Palembang. As the names in Plaju were changed by the company and not by the government, there were no streets with names of heroes. ${ }^{21}$ All that the company did was change the Dutch 'Weg' into the English word 'Road', in order to adapt to the current political situation after Independence that tended to be hostile towards Dutch companies and to reflect the company's part-English ownership (Table 12.2).

In contrast to the projective system, Asians tend to name streets and places after the peculiar characteristics of their kampong and landmarks related to daily life experiences. For example, in Singapore the Armenian Street (as it was called

21 One exception is Captain Abdullah who was killed in Plaju in 1947, in the War of Independence. A street in Plaju was named after him and a statue dedicated to him and his soldiers was unveiled in the 1970s (Mangkualam 1986). 
TABLE 12.2 The change of street names in the BPM Plaju complex

\begin{tabular}{|c|c|c|c|}
\hline Before 1949 & $1949^{-1959}$ & $1959-1965$ & After 1965 \\
\hline Weg 23 & Melati Road 23 & Djl. Melati (Djl. 23) & Jl. Melati \\
\hline Weg 23 a & Kamboja Road 23 a & Djl. Kamboja (Djl. 23a) & Jl. Kamboja \\
\hline Weg 24 & Tjempaka Road 24 & Djl. Tjempaka (Djl. 24) & Jl. Cempaka \\
\hline Weg 24 a & Kemang Road 24 a & Djl. Kemang (Djl. 24 a) & Jl. Kemang \\
\hline Weg 25 & Mawar Road 25 & Djl. Mawar (Djl. 25) & Jl. Mawar \\
\hline Weg 26 & Teratai Road 26 & Djl Teratai (Djl. 26) & Jl. Teratai \\
\hline Weg 27 & Terusan Road 27 & Djl. Terusan (Djl. 27) & Jl. Teratai \\
\hline Weg 30 & Beringin Road 30 & Djl, Beringin (Djl. 3o) & Jl. Beringin \\
\hline Weg 31 & Antara Road 31 & Djl. Antara (Djl. 31) & Jl. Antara \\
\hline Weg 32 & Bakaran Road 32 & Djl. Bakaran (Djl. 32) & Jl. Bakaran \\
\hline Weg 33 & Utama Road 33 & Djl. Utama (Djl. 33) & Jl. Utama \\
\hline Weg 34 & Rengas Road 34 & Djl. Rengas (Djl. 34) & Jl. Rengas \\
\hline Weg 35 & Upaya Road 35 & Djl. Upaya (Djl, 35) & Jl. Upaya \\
\hline Weg 37 & Durian Road 37 & Djl. Durian (Djl. 37) & Jl. Durian \\
\hline Weg 39 & Kelapa Sawit Road 39 & Djl. Kelapa Sawit (Djl. 39) & Jl. Kelapa Sawit \\
\hline Weg 40 & Pengantingan Road 40 & Djl. Pengantingan (Djl. 40) & Jl. Pengantingan \\
\hline Weg 41 & Permai Road 41 & Djl. Permai (Djl. 41) & Jl. Permai \\
\hline Weg 43 & Petanang Road 43 & Djl. Petanang (Djl. 43) & Jl. Petanang \\
\hline Weg 46 & Kenari Road 46 & Djl. Kenari (Djl. 46) & Jl. Kenari \\
\hline Weg 47 & Tembesu Road 47 & Djl. Tembesu (Djl. 47) & Jl. Tembesu \\
\hline Weg 48 & Djati Road 48 & Djl. Djati (Djl. 48) & Jl. Jati \\
\hline Weg 49 & Tjemara Road 49 & Djl. Tjemara (Djl. 49) & Jl. Cemara \\
\hline Weg 49 & Lamtaro Road 49 & Djl. Lamtaro (Djl. 49) & Jl. Lamtaro \\
\hline Weg $5^{\circ}$ & Lontar Road 50 & Djl. Lontar (Djl. 5o) & Jl. Lontar \\
\hline Weg 51 & Waru Road $5^{1}$ & Djl. Waru (Djl. 51) & Jl. Waru \\
\hline Weg 51 & Bluntas Road 51 & Djl. Bluntas (Djl. 51) & Jl. Bluntas \\
\hline Weg 53 & Ketapang Road 53 & Djl. Ketapang (Djl. 53) & Jl. Ketapang \\
\hline Weg 54 & Telaga Road 54 & Djl. Telaga (Djl. 54) & Jl. Telaga \\
\hline Weg 55 & Kenanga Road 55 & Djl. Kenanga (Djl. 55) & Jl. Kenanga \\
\hline Weg 56 & Kebon Djahe Road ${ }_{5}^{6}$ & Djl. Kebon Djahe $\left(\mathrm{Djl},{ }_{5} 6\right)$ & Jl. Kebon Jahe \\
\hline Weg 57 & Anggrek Road 57 & Djl. Anggrek (Djl. 57) & Jl. Anggrek \\
\hline Weg 70 & Rampai Road 70 & Djl. Rampai (Djl, 7o) & Jl. Rampai \\
\hline Weg 71 & Bakung Road 71 & Djl. Bakung (Djl, 71) & Jl. Bakung \\
\hline
\end{tabular}

SOURCE: ARSIP UP III PERTAMINA PLAJU, MAPS OF PLAJU FROM 1949, 1956 AND 1959 
by the British overlord) was called Seng Po Toa Chu Au (Behind the big house Seng Po) by the Chinese inhabitants (Yeoh 1996:229-231). In the same vein, after 1949 'Asian' names were added to the road numbers in Plaju. For instance, Road $3_{1}$ became Antara Road 31, because it ran 'between' (antara in Indonesian) the refinery and the housing complex. Road 30 was renamed Beringin Road 30, because a banyan tree (waringin or beringin) stood there. This Asian way of nomenclature introduced after Independence confirms the impression that the public symbols of Plaju were gradually Indonesianized. The Indonesianization of Plaju was different from other places, however, because no names of heroes were imposed by the state; the place making was bottom-up based on local characteristics of the landscape.

Mounting tension over New Guinea resulted in the nationalization of Dutch companies in Indonesia in 1957-1958 (Mackie 2002:405). Because of its partBritish status, the врм escaped nationalization, but the massive departure of Dutch staff caused instability in the company. Within six months the company replaced almost all its Dutch managers and staff with English and American personnel or promoted Indonesian workers to more responsible positions (Bartlett et al., 1986:116). In short, BPM wanted to rid the enterprise of its Dutch image and promote instead both an international and local image. Around 1955, the company's name в Рм became Shell Petroleum. Other oil companies in Indonesia followed this example; the Nederlandsche Koloniale Petroleum Maatschappij (a subsidiary of Standard Oil) and Nederlandsche Pacific Petroleum Maatschappij changed their names into Stanvac and Caltex Pacific (Basundoro 2004:15).

The naming policies of the foreign oil companies could eventually not stop the progressive nationalization, which was given juridical footing by the implementation of Law 44/196o (Bartlett et al., 1986:173). Shell and other foreign oil companies were forced to accept a gradual take-over by the Indonesian state. This transfer would take almost five years (1960-1965). During that period, names of streets and places in Plaju were further Indonesianized. All English names carrying the word 'Road' were replaced by the Indonesian word 'Djalan' and after 1965 the projective system of giving names was abandoned completely. In this way names of streets inside the complex were soon no different from street names in the kampongs outside the complex.

At the same time as the street names in Plaju were changed, names of buildings were replaced following a similar pattern. Dutch names of important buildings were changed into English and later into Indonesian names (Table 12.3). 
TABLE 12.3 Names of important buildings in Plaju

\begin{tabular}{lll}
\hline before 1949 & 1949-1959 & after 1959 \\
\hline Societeit Unitas & Club Unitas & Arena Ria \\
Societeit Kranie & Club House & Balai Ria \\
Bioscoop & Cinema & Aneka Ria \\
Hollandsch-Inlandsche & Indonesian Elementary School & Sekolah Dasar Bakaran \\
School & & \\
& & \\
\hline
\end{tabular}

SOURCE: ARCHIVE OF UP III PERTAMINA PLAJU, MAPS OF PLAJU FROM 1949, 1956, 1959

\section{Conclusion}

Plaju was a symbol of modernity in the early and mid-twentieth century, both because of the capital-intensive industry and the modern facilities offered to the labourers and white-collar staff. At first, the symbols of modernity were very much also symbols of Dutch colonialism: the modern villas, club, tennis court, etcetera were exclusively used by Europeans. The Indonesianization of the oil refinery started in the 1930s, long before political independence was achieved, when Indonesians gradually entered the middle echelons of the refinery. They did not only get betterpaid jobs, but also appropriated various symbols of modernity. For instance, they established a social club of their own, where they experimented with a modern lifestyle (such as ballroom dancing) and spoke a hybrid language containing Dutch words. At the same time, also the European staff became Indonesianized, when they were stimulated to learn Indonesian and wear Indonesian dress (sarong and kabaya).

After Independence, the Indonesianization of the refinery progressed: more Indonesians were promoted to top ranks and British and Americans also replaced Dutch personnel. The Indonesianization of Plaju also took other forms, as when the Indonesian army occupied a considerable number of houses. The Indonesianization of Plaju took also a symbolic form, because names of streets and important buildings were changed into Indonesian. In the case of Plaju, it is significant that the process of name change occurred more slowly than in most other places, and more importantly, that names were first changed from Dutch to English and only in a second phase from English to Indonesian. For company directors, it was more important to avoid a Dutch image than to adopt an Indonesian appearance. For the same reason, new Indonesian street names refer only to local situations and not to national heroes. 
In short, the Indonesianization of the oil refinery in Plaju was exceptional compared to major cities in Indonesia, firstly, because it started relatively early before 1945, and secondly, because it progressed relatively slowly after 1945. The explanation for this slow process was probably the relative isolation of Plaju. The political storms in Palembang were only a breeze by the time they reached the refinery. The company, throughout its own name changes, remained in control of the refinery until the mid-196os. The municipal government of Palembang tried to include Plaju in its jurisdiction and even built an office for the kampong head in front of the gate of the Plaju housing complex (Manurung et al., 1956:190). The establishment of this office as a symbol of the Palembang municipality, and by extension the national state, did not affect the exclusiveness of Plaju.

According to Wolfram-Seifert (cited by Taal 2003), the exclusiveness of the Plaju refinery came to an end when the Ampera Bridge was built in 1965 . Even then, however, Plaju was not totally integrated into the city of Palembang. The refinery came under the direct control of the central government in Jakarta and as a result the newly created symbols had a more national rather than regional character. For example, the name of the refinery changed from PT Shell Indonesia into PN Permina and after the fusion in 1965 with Pertamin it was eventually renamed Pertamina (Taal 2003:79). Furthermore, most of the refinery workers were recruited from outside Palembang with the result that people from Palembang did not regard the area as a part of Palembang. The Indonesianization of the symbols of modernity of Plaju did not entail a further integration of the refinery into Palembang.

\section{References}

Ahimsa Putra, Heddy Shri (2002). 'Tanda, simbol, budaya dan ilmu budaya', paper presented at the 'Cultural Seminar', Faculty of Cultural Sciences, Gadjah Mada University, Yogyakarta, 13 June.

Alumni Pendidikan Tehnik Minyak Plaju (1999). Sejarah tehnikminyak Plaju 1942-1945: Kepeloporan semangat juang 1945. Palembang: Penerbit Unsri.

Bartlett, Anderson G. et al. (1986).Pertamina:Perusahaan minyaknasional.Jakarta: Inti Idayu Press.

Basundoro, Purnawan (2004). 'Nasionalisasi dengan jalan damai: Indonesianisasi usaha pertambangan minyak di Indonesia', paper presented at the workshop 'The economic side of decolonization', Yogyakarta, 16-19 August.

Broersma, R. (1921). Palembangsche verkenningen. [S.l.: s.n.; offprint from the Locomotief.] 
Bruyn Kops, G.F. de (1919). Overzicht van Zuid-Sumatra. Amsterdam: Zuid-Sumatra Instituut.

Clercq, F.S.A. de (1877). 'De hoofdplaats Palembang', Tijdschrift van het Aardrijkskundig Genootschap 2:174-175.

Colombijn, Freek (2006). 'Sign of the times: Symbolic change around Indonesian independence', in: Peter J.M. Nas and Annemarie Samuels (eds), Hypercity: The symbolic side of urbanism, pp. 113-144. London, Bahrain and New York: Kegan Paul.

Colombijn, Freek (with the assistance of Martine Barwegen) (2010). Under construction: The politics of urban space and housing during the decolonization of Indonesia, 1930-196o. Leiden: KITLV Press.[Verhandelingen KITLV 246.]

Dillistone, F.W. (2002). The power of symbols. Yogyakarta: Kanisius.

Evers, Hans-Dieter (1993). 'Simbolisme perkotaan di Indonesia: Kasus Padang "Kota Tercinta"', Prisma 22(4):81-91.

Fasum Pertamina Plaju (n.y.). Denah perumahan Plaju dan Bagus Kuning tahun 1905-1957.

Hanafiah, Djohan (ed.) (1998). Sejarah perkembangan pemerintah kotamadya Daerah Tingkat II Palembang. Palembang: Pemerintah Kotamadya Daerah Tingkat II Palembang.

Handinoto (1996). Perkembangan kota dan arsitektur kolonial Belanda di Surabaya 1870-1940. Surabaya: Lembaga Penelitian dan Pengabdian Kepada Masyarakat, Universitas Kristen Petra and Yogyakarta: Andi.

Jong, L. de (2002). The collapse of a colonial society: The Dutch in Indonesia during the Second World War. Leiden: KITLV Press. [Verhandelingen KITLV 206.]

Kerchman, J.M.W. (ed.) (1930). 25Jaren decentralisatie in Nederlandsch-Indië: 1905-1930. Semarang: Vereeniging voor Locale Belangen.

Lindblad, J. Thomas (2002). 'The late colonial state and economic expansion, 19001930s', in: Howard Dick et al., The emergence of a national economy: An economic history of Indonesia, 1800-200o, pp. 111-152. St Leonards: Allen and Unwin and Leiden: KITLV Press.

Lindblad, J. Thomas (2008). Bridges to new business: The economic decolonization of Indonesia. Leiden: KITLV Press. [Verhandelingen KITLV 245.]

Mackie, J.A.C. (2002). 'Periode 1941-1965 sebagai selingan dalam pembentukan ekonomi nasional: Bagaimana sebaiknya kita menafsirkan', in: J.Th. Lindblad (ed.), Fondasi historis ekonomi Indonesia, pp. 394-415. Yogyakarta: Pusat Studi Sosial Asia Tenggara, Universitas Gadjah Mada.

Manurung, P.K. et al. (1956). Sumatera Selatan. Palembang: Djawatan Penerangan Propinsi Sumatra Selatan.

Mangkualam, H. Asnawi (1986). Perang kota 120 jam rakyat Palembang. Jakarta: Aksara Baru. 
McGee, T.G. (1967). The Southeast Asian city: A social geography of the primate cities of Southeast Asia. London: Bell.

Nas, Peter J.M. (1993). 'Jakarta, city full of symbols: An essay in symbolic ecology', in: Peter J.M. Nas (ed.), Urban symbolism, pp. 13-37. Leiden: Brill.

Nas, Peter J.M. (1995). 'Palembang: Venice of the East', in: Peter J.M. Nas (ed.), Issues in urban development: Case studies from Indonesia, pp. 132-142. Leiden: Research School cNws. [CNws Publications 33.]

Nas, Peter J.M., Rivke Jaffe and Annermarie Samuels (2006). 'Urban symbolical ecology and the hypercity: State of the art and challenges for the future', in: Peter J.M. Nas and Annemarie Samuels (eds), Hypercity: The symbolic side of urbanism, pp. 1-19. London, Bahrain and New York: Kegan Paul.

Pattynama, Pamela (2004). 'Keluarga Indis: Kehidupan sehari-hari pada masa sebelum perang di Batavia', in: Joost Coté and Loes Westerbeek (eds), Recalling the Indies: Kebudayaan kolonial dan identitas poskolonial, pp. 29-57. Yogyakarta: Syarikat Indonesia.

Peeters, Jeroen (1997). Kaum tuo, kaum mudo: Perubahan religius di Palembang 18211942. Jakarta: INIS.

Pertamina (1995). Perkembangan kilang Plaju/Sungai Gerong (Kilang Musi) kurun waktu 1895-1995. Jakarta: Perpustakaan Pusat Pertamina.

Purwanto, Bambang (1997). 'Minyak dan ekonomi di karesidenan Jambi dan Palembang pada akhir masa kolonial', Lembaran Sejarah 1(1):81-102.

Rivai, Liza (2001). Sejarah pendidikan di kota Palembang. Yogyakarta: Philosophy Press.

Stibbe, D.G. (ed.) (1919). Encyclopaedie van Nederlandsch-Indië vol. 3. 's Gravenhage: Nijhoff and Leiden: E.J. Brill. [second edition.]

Taal, Sandra (2003). Between ideal and reality: Images of Palembang. $[\mathrm{PhD}$ thesis, Leiden University.]

Vlekke, Bernard H.M. (1959). Nusantara: A history of Indonesia. The Hague: Van Hoeve. [Originally published by Harvard University Press, 1943.]

Wertheim, W.F. (1959). Indonesian society in transition: A study of social change. The Hague and Bandoeng: Van Hoeve. [2nd revised edition.]

Wertheim, W.F. (1999). Masyarakat Indonesia dalam transisi: Studi perubahan sosial. Yogyakarta: Tiara Wacana Yogya.

Yeoh, Brenda S.A. (1996). Contesting space: Power relations and the urban built environment in colonial Singapore. Kuala Lumpur: Oxford University Press.

Zed, Mestika (2003). Kepialangan politik dan revolusi Palembang 1900-1950. Jakarta: $\mathrm{LP}_{3} \mathrm{ES}$. 